\title{
Myeloperoxidase-Mediated Platelet Release Reaction
}

\author{
Robert A. Clark, Department of Medicine, Boston University School of Medicine, \\ and University Hospital, Boston, Massachusetts 02118 \\ SEYMOUR J. KLEBANOFF, Department of Medicine, University of Washington School of \\ Medicine, Seattle, Washington 98195
}

A B S T RACT The ability of the neutrophil myeloperoxidase-hydrogen peroxide-halide system to induce the release of human platelet constituents was examined. Both lytic and nonlytic effects on platelets were assessed by comparison of the simultaneously measured release of a dense-granule marker, $\left[{ }^{3} \mathrm{H}\right]$ serotonin, and a cytoplasmic marker, $\left[{ }^{14} \mathrm{C}\right]$ adenine. Incubation of platelets with $\mathrm{H}_{2} \mathrm{O}_{2}$ alone $\left(20 \mu \mathrm{M} \mathrm{H}_{2} \mathrm{O}_{2}\right.$ for $\left.10 \mathrm{~min}\right)$ resulted in a small, although significant, release of both serotonin and adenine, suggesting some platelet lysis. Substantial release of these markers was observed only with increased $\mathrm{H}_{2} \mathrm{O}_{2}$ concentrations $(>0.1 \mathrm{mM})$ or prolonged incubation (1-2 h).

Serotonin release by $\mathrm{H}_{2} \mathrm{O}_{2}$ was markedly enhanced by the addition of myeloperoxidase and a halide. Under these conditions, there was a predominance of release of serotonin (50\%) vs. adenine (13\%), suggesting, in part, a nonlytic mechanism. Serotonin release by the complete peroxidase system was rapid, reaching maximal levels in 2-5 min, and was active at $\mathrm{H}_{2} \mathrm{O}_{2}$ concentrations as low as $10 \mu \mathrm{M}$. It was blocked by agents which inhibit peroxidase (azide, cyanide), degrade $\mathrm{H}_{2} \mathrm{O}_{2}$ (catalase), chelate $\mathrm{Mg}^{2+}$ (EDTA, but not EGTA), or inhibit platelet metabolic activity (dinitrophenol, deoxyglucose).

These results suggest that the myeloperoxidase system initiates the release of platelet constituents primarily by a nonlytic process analogous to the platelet release reaction. Because components of the peroxidase system (myeloperoxidase, $\mathrm{H}_{2} \mathrm{O}_{2}$ ) are secreted by activated neutrophils, the reactions described here may have implications for neutrophilplatelet interaction in sites of thrombus formation.

Portions of this work have appeared in abstract form: Clin. Res. 1976. 24: 305A; and Clin. Res. 1977. 25: 474A.

Dr. Clark is the recipient of Research Career Development Award CA00441 from the National Institutes of Health.

Received for publication 3 July 1978 and in revised form 25 September 1978.

\section{INTRODUCTION}

When the polymorphonuclear leukocyte $(\mathrm{PMN})^{1}$ is activated by phagocytosis, contact with nonphagocytosable immune reactant-coated surfaces, or exposure to certain soluble stimuli, it undergoes both metabolic activation and degranulation (1-3). Although the primary role of these processes is considered to be the killing of ingested microorganisms within the phagocytic vacuole, leakage or secretion of toxic agents into the extracellular fluid can occur. Thus, the metabolic burst results in the formation of several reactive species of partially reduced oxygen, including superoxide anion, hydrogen peroxide $\left(\mathrm{H}_{2} \mathrm{O}_{2}\right)$, and hydroxyl radical $(2,3)$, and some of these agents have been detected in the extracellular fluid adjacent to the activated PMN (4-8). Degranulation can result in the emptying of granule enzymes, such as acid hydrolases and myeloperoxidase, into the extracellular fluid (9-13). The potential biological effects of these PMN secretory products have attracted considerable interest.

Myeloperoxidase (MPO) plus $\mathrm{H}_{2} \mathrm{O}_{2}$ and a halide constitute a potent microbicidal system which is operative in the PMN $(2,3,14)$. This system is also toxic to several types of mammalian cells, including spermatozoa (15), erythrocytes (16), leukocytes (17), and tumor cells (18), raising the possibility that MPO and $\mathrm{H}_{2} \mathrm{O}_{2}$ released from activated $\mathrm{PMN}$ may affect nearby host cells. Phagocytosing PMN exert a cytotoxic effect on adjacent mammalian tumor cells which is mediated by the release of MPO and $\mathrm{H}_{2} \mathrm{O}_{2}$ (5). Extracellular activity of MPO and $\mathrm{H}_{2} \mathrm{O}_{2}$ is further indicated by the fact that protein iodination by phagocytosing PMN, a phenomenon mediated by the MPO system, occurs in both extracellular and intracellular sites $(19,20)$. Secreted $\mathrm{H}_{2} \mathrm{O}_{2}$

\footnotetext{
${ }^{1}$ Abbreviations used in this paper: DNP, dinitrophenol; DOG, 2-deoxy-D-glucose; MPO, myeloperoxidase; PBA, sodium phosphate buffer, $0.1 \mathrm{M}, \mathrm{pH} 6.5$, with human albumin $1 \mathrm{mg} / \mathrm{ml}$; PMN, polymorphonuclear leukocyte(s).
} 
alone may exert nonenzymatic effects on certain types of mammalian cells $(4,8)$.

Previous investigators have suggested the possibility of in situ interaction between PMN and platelets $(8,21-23)$. The studies of Levine et al. (8) demonstrated an in vitro effect of activated $\mathrm{PMN}$ on platelets mediated by secreted $\mathrm{H}_{2} \mathrm{O}_{2}$. Platelets which were preincubated with phagocytosing $\mathrm{PMN}$ or with an $\mathrm{H}_{2} \mathrm{O}_{2}$ generating enzyme system had impaired aggregation responses, and this effect was inhibited by catalase. Other studies have reported effects of reagent $\mathrm{H}_{2} \mathrm{O}_{2}$ on various aspects of platelet physiology (24-28). In this paper, we describe the initiation of the release reaction in human platelets by the $\mathrm{MPO}-\mathrm{H}_{2} \mathrm{O}_{2}$-halide system.

\section{METHODS}

Platelet preparation. All processing was performed at room temperature with plastic tubes, syringes, and pipettes. Venous blood was drawn from normal adult volunteers, with potassium EDTA (K-EDTA) as the anticoagulant $(10 \mathrm{ml}$ of blood plus $0.2 \mathrm{ml}$ of a $10 \%$ solution of K-EDTA). After centrifugation at $200 \mathrm{~g}$ for $10 \mathrm{~min}$, the upper one-half of the platelet-rich plasma layer $(\cong 2 \mathrm{ml})$ was carefully aspirated without disturbing the lower erythrocyte layer. $\left[{ }^{3} \mathrm{H}\right]$ serotonin (hydroxytryptamine binoxalate, $5-\left[1,2{ }^{3} \mathrm{H}(\mathrm{N})\right]$ in $2 \%$ ethanol, $\cong 25 \mathrm{Ci} / \mathrm{mmol}$, New England Nuclear, Boston, Mass.) and $\left[{ }^{14} \mathrm{C}\right]$ adenine (adenine $\left[8^{-14} \mathrm{C}\right]$ in $0.01 \mathrm{~N} \mathrm{HCl}, \cong 50 \mathrm{mCi} / \mathrm{mmol}$, New England Nuclear) were added to the platelet-rich plasma to final concentrations of $0.2 \mu \mathrm{M}$ serotonin and $20 \mu \mathrm{M}$ adenine. In some experiments, $\left[{ }^{14} \mathrm{C}\right]$ serotonin (5-hydroxytryptamine binoxalate $\left[2-{ }^{14} \mathrm{C}\right]$ in $2 \%$ ethanol, $\cong 50 \mathrm{mCi} / \mathrm{mmol}$, New England Nuclear) and $\left[{ }^{3} \mathrm{H}\right]$ adenine (adenine- ${ }^{3} \mathrm{H}[\mathrm{G}], \cong 20$ $\mathrm{Ci} / \mathrm{mmol}$, New England Nuclear) were used in similar concentrations. The platelet-rich plasma-serotonin-adenine mixture was incubated at room temperature for $\mathbf{4 0} \mathrm{min}$ with occasional gentle mixing. It was then centrifuged at $500 \mathrm{~g}$ for 10 min and the platelet pellet was gently washed with $5 \mathrm{ml}$ of $0.1 \mathrm{M}$ sodium phosphate buffer, $\mathrm{pH} 6.5$, containing human albumin (Sigma Chemical Co., St. Louis, Mo.), $1 \mathrm{mg} / \mathrm{ml}$ (PBA). After centrifugation at $600 \mathrm{~g}$ for $10 \mathrm{~min}$, the platelet pellet was again suspended in $5 \mathrm{ml}$ of PBA. An aliquot of $0.01 \mathrm{ml}$ was diluted in $0.99 \mathrm{ml}$ of PBA, and the platelets in this suspension were counted in duplicate in a hemocytometer. The stock platelet suspension was then adjusted to contain $10^{8}$ platelets/ $\mathrm{ml}$ of PBA.

Release assay. Radiolabeled platelets $(0.05-\mathrm{ml}$ sample of stock suspension containing $5 \times 10^{6}$ platelets) were incubated with the system components as detailed in the legends to the tables and figures. Incubations were performed in $12 \times 75$ $\mathrm{mm}$ polystyrene tubes with a total volume of $0.5 \mathrm{ml}$, in a $37^{\circ} \mathrm{C}$ waterbath shaker oscillating 60 times/min. Immediately after incubation, the samples were centrifuged at $550 \mathrm{~g}$ for 10 $\min$ at $4^{\circ} \mathrm{C}$. A portion of $0.2 \mathrm{ml}$ of each sample supernate was placed in a liquid scintillation counter vial, $15 \mathrm{ml}$ of Aquasol (New England Nuclear) was added, and counts of ${ }^{3} \mathrm{H}$ and ${ }^{14} \mathrm{C}$ determined in a Beckman LS-100 counter (Beckman Instruments, Inc., Spinco Div., Palo Alto, Calif.). In each experiment, all samples were run in duplicate, and the values averaged. Standards included blank tubes $\left(0.2 \mathrm{ml} \mathrm{H}_{2} \mathrm{O}\right)$, platelet standards $(0.05-\mathrm{ml}$ platelets), and maximum release standards $(0.05-\mathrm{ml}$ platelets plus $0.45 \mathrm{ml} 1 \%$ Triton X-100 [Sigma Chemical Co.] which was centrifuged as above and a 0.2-ml portion counted). The blank was subtracted from all samples and the release of each isotope was calculated as a percent of the maximum release standard. The release of both serotonin and adenine by Triton X-100 (maximum release standard) was essentially equal to the total contained in the platelet standard.

Special reagents. MPO was prepared from canine PMN by the method of Agner (29) through the end of step 6. Peroxidase activity was determined by the o-dianisidine method (30); $1 \mathrm{U}$ of activity is that causing the usage of $1 \mu \mathrm{mol}$ of substrate/min at $25^{\circ} \mathrm{C}(16)$. MPO prepared from human PMN by the method of Olsson et al. (31) was kindly supplied by Dr. Inge Olsson. $\mathrm{H}_{2} \mathrm{O}_{2}$ (30\% solution) was obtained from Fisher Scientific Co., Fair Lawn, N. J. Dinitrophenol, 2-deoxy-Dglucose, EDTA, K-EDTA, and EGTA were obtained from Sigma Chemical Co. Stock solutions of EDTA and EGTA were made at $0.1 \mathrm{M}$ with the $\mathrm{pH}$ adjusted to $7.0 ; 0.05 \mathrm{M} \mathrm{MgCl}_{2}$ was added to the stock EGTA to assure saturation of $\mathrm{Mg}^{2+}$-binding capacity (Mg-EGTA). Catalase (beef liver, $6.7 \mathrm{mg} / \mathrm{ml}, 62,900$ U/mg) was from Worthington Biochemical Corp., Freehold, $\mathrm{N}$. J. $1 \mathrm{U}$ of catalase is that amount which catalyzes the oxidation of $1 \mu \mathrm{mol} \mathrm{H}_{2} \mathrm{O}_{2} / \mathrm{min}$ at $25^{\circ} \mathrm{C}, \mathrm{pH} 7.0$.

Statistics. Standard error was used throughout as an estimate of variance, and means were compared with Student's $t$ test.

\section{RESULTS}

Incubation of $\left[{ }^{3} \mathrm{H}\right]$ serotonin-labeled human platelets with MPO, $\mathrm{H}_{2} \mathrm{O}_{2}(20 \mu \mathrm{M})$, and chloride resulted in rapid and substantial release of the labeled amine which reached about two-thirds of maximum levels within 2 $\min$ (Fig. 1). Very little additional release was observed

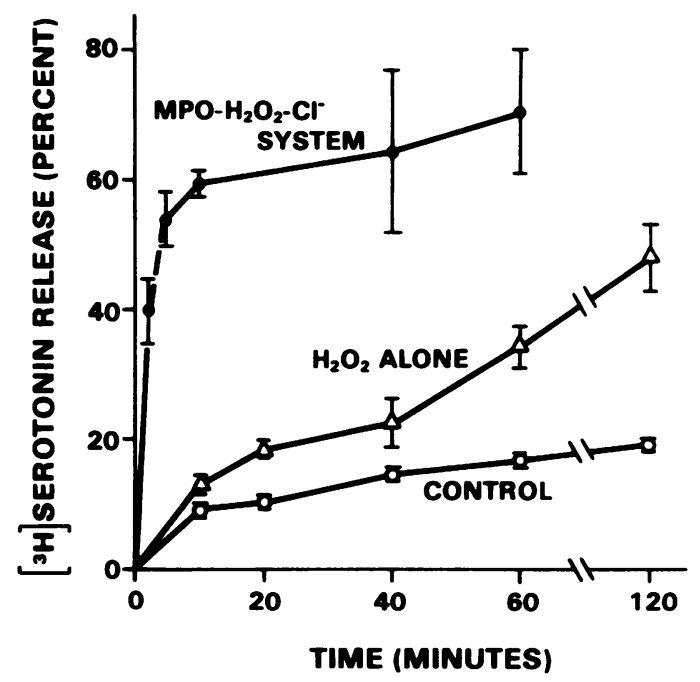

FIGURE 1 Kinetics of the release of serotonin from platelets by the MPO- $\mathrm{H}_{2} \mathrm{O}_{2}$-chloride system and by $\mathrm{H}_{2} \mathrm{O}_{2}$ alone. Control samples $(\mathrm{O})$ contained $0.03 \mathrm{M}$ sodium phosphate buffer

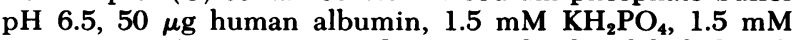
$\mathrm{MgSO}_{4}, 0.067 \mathrm{M} \mathrm{Na}_{2} \mathrm{SO}_{4}$, and $5 \times 10^{6}$ platelets labeled with $\left[{ }^{3} \mathrm{H}\right]$ serotonin. In the experimental samples, $\mathrm{Na}_{2} \mathrm{SO}_{4}$ was replaced by $0.1 \mathrm{M} \mathrm{NaCl}$; either $4 \mathrm{mU}$ of MPO (canine) and $20 \mu \mathrm{M} \mathrm{H}_{2} \mathrm{O}_{2}(\Theta)$, or $20 \mu \mathrm{M} \mathrm{H} \mathrm{H}_{2} \mathrm{O}_{2}$ alone $(\Delta)$ was added. Total volume was $0.5 \mathrm{ml}$, and incubation time was varied as indicated. Data represent mean $\pm \mathrm{SE}$ of six experiments. 
after 5-10 min. The $10-\mathrm{min}$ period was used routinely as maximal levels were achieved and because sample processing was difficult when periods shorter than this were employed. There was slow leakage of serotonin throughout the incubation period from control platelets suspended in the buffer alone. In the absence of MPO, $\mathrm{H}_{2} \mathrm{O}_{2}(20 \mu \mathrm{M})$ caused minimal release above control levels at $10 \mathrm{~min}$; but, with prolonged incubation, substantial release was detected. However, this always remained well below the level observed with the complete MPO system. The effect of $\mathrm{H}_{2} \mathrm{O}_{2}$ in the absence of MPO did not require halides because the same results were observed when chloride was omitted. In subsequent figures and tables, the release in control samples has been subtracted from that in experimental samples, with the mean control release indicated in the footnotes.

In the presence of MPO and chloride, $\mathrm{H}_{2} \mathrm{O}_{2}$ was effective in initiating serotonin release at concentrations of $10 \mu \mathrm{M}$ or higher (Fig. 2). In the absence of MPO, release of serotonin by $\mathrm{H}_{2} \mathrm{O}_{2}$ during a 10 -min incubation was substantial only at concentrations well above $0.1 \mathrm{mM}$. Examination of the $\mathrm{H}_{2} \mathrm{O}_{2}$ dose-response curves (Fig. 2) indicates nearly a 2 -log greater potency in the presence of MPO than in its absence.

The requirements for MPO-mediated serotonin release from platelets are explored further in Table $I$. Several halides (chloride, iodide, bromide) and the

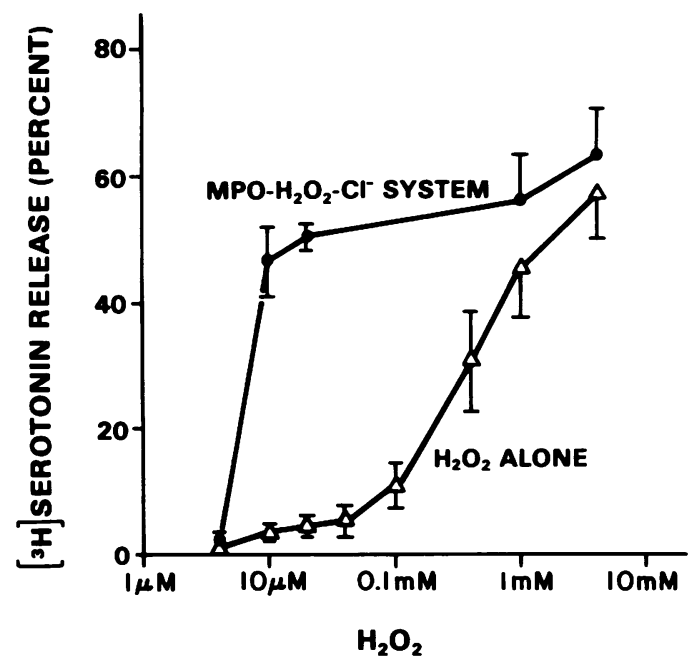

FIGURE 2 Effect of varying $\mathrm{H}_{2} \mathrm{O}_{2}$ concentrations on the release of serotonin from platelets by the MPO- $\mathrm{H}_{2} \mathrm{O}_{2}$-chloride system. Conditions were as described in Fig. 1 except that the $\mathrm{H}_{2} \mathrm{O}_{2}$ concentration was varied as indicated. The incubation time was $10 \mathrm{~min}$. Serotonin release in samples containing the complete peroxidase system $(O)$ and in samples containing $\mathrm{H}_{2} \mathrm{O}_{2}$ without MPO $(\Delta)$ are illustrated. Data represent mean $\pm \mathrm{SE}$ of six experiments. Serotonin release in control samples (mean $9.2 \pm 0.6 \%$ ) was subtracted from that in experimental samples. pseudohalide, thiocyanate, were effective as cofactors. When each component of the system was omitted or when MPO was heated, there was a major loss of serotonin-releasing activity, indicating requirements for the active enzyme, $\mathrm{H}_{2} \mathrm{O}_{2}$, and a cofactor. However, a small but significant $(P<0.05)$ amount of serotonin release was detected in the absence of MPO, suggesting a minor effect of $\mathrm{H}_{2} \mathrm{O}_{2}$ alone (Fig. 1). MPO isolated from both dog and human PMN was effective.

The MPO system also induced the release of $\left[{ }^{14} \mathrm{C}\right]-$ adenine from labeled human platelets (Table I), although the percent release was much lower than that observed with serotonin. Results with adenine were parallel to those with serotonin, as dog and human MPO were effective; each of the cofactors could be employed (data for iodide, bromide, and thiocyanate not shown), and release was decreased when each component of the system was omitted or when the MPO was heated ( $P<0.01$ for each comparison). However, the release of adenine observed on deletion of MPO or the halide or on heating the MPO was approximately one-half of that found with the complete MPO system. Thus, it appeared that under the conditions employed, $\mathrm{H}_{2} \mathrm{O}_{2}$ alone was responsible for about one-half of the adenine release, but only a small proportion of the serotonin release, and that the addition of MPO resulted in slight enhancement of adenine release, but a striking stimulation of serotonin release. Results in both the serotonin and adenine release systems were confirmed in parallel experiments employing different radioisotopes, i.e., $\left[{ }^{14} \mathrm{C}\right]$ serotonin and $\left[{ }^{3} \mathrm{H}\right]$ adenine (data not shown).

The effect of a number of inhibitors on MPO-mediated serotonin release is shown in Table II. The peroxidase inhibitors, azide and cyanide, blocked release essentially completely. Release was also inhibited by the addition of catalase, but not heated catalase. Chelation of $\mathrm{Ca}^{2+}$ and $\mathrm{Mg}^{2+}$ by $10 \mathrm{mM}$ EDTA inhibited serotonin release, but $1 \mathrm{mM}$ EDTA was ineffective. Selective chelation of $\mathrm{Ca}^{2+}$ by $10 \mathrm{mM} \mathrm{Mg}$ EGTA had no effect. These data suggest a requirement for $\mathrm{Mg}^{2+}$, but not $\mathrm{Ca}^{2+}$, for maximal MPO-induced release of serotonin from platelets. The standard reaction mixture contained $1.5 \mathrm{mM} \mathrm{Mg}^{2+}$ and no added $\mathrm{Ca}^{2+}$. Dinitrophenol (DNP), an inhibitor of oxidative phosphorylation, caused a partial, but significant, decrease in serotonin release, as did 2-deoxy-D-glucose (DOG), a competitive inhibitor of glucose usage. The most marked inhibition was observed when both DNP and DOG were present $(P<0.001$ vs. complete MPO system; $P<0.005$ vs. DOG or DNP alone). The low level of adenine release induced by the MPO system was partially inhibited by azide, cyanide, catalase, EDTA, and DNP, but was unaffected by heated catalase, EGTA, and DOG. None of the inhibitors in the concentrations employed caused any release of 
TABLE I

Release of $\left[{ }^{3} \mathrm{H}\right]$ Serotonin and $\left[{ }^{14} \mathrm{C}\right]$ Adenine from Platelets by the MPO System*

\begin{tabular}{|c|c|c|c|c|c|}
\hline \multirow[b]{2}{*}{ Supplements } & \multicolumn{4}{|c|}{$\left[{ }^{3} \mathbf{H}\right]$ Serotonin release } & \multirow{2}{*}{ 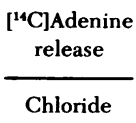 } \\
\hline & Chloride & Iodide & Bromide & Thiocyanate & \\
\hline & \multicolumn{4}{|c|}{$\%$} & $\%$ \\
\hline \multicolumn{6}{|l|}{ MPO $($ canine $)+\mathrm{H}_{2} \mathrm{O}_{2}$} \\
\hline+ cofactor & $50.0 \ddagger \S(24)$ & $19.4 \S(11)$ & $25.8 \$(6)$ & $24.4 \S(6)$ & $13.4 \S(22)$ \\
\hline MPO omitted & $4.0^{\prime \prime} \quad(12)$ & $3.5^{11}(7)$ & $4.2^{\prime \prime}(3)$ & $10.4^{\prime \prime}(3)$ & $8.3 \$(12)$ \\
\hline $\mathrm{H}_{2} \mathrm{O}_{2}$ omitted & $0.3 \quad(7)$ & $1.3(7)$ & $1.9 \quad(3)$ & $1.9 \quad(3)$ & $1.0(7)$ \\
\hline Cofactor omitted & (8) & $0 \quad(8)$ & $0 \quad(8)$ & $0 \quad(8)$ & $5.9 \$(8)$ \\
\hline MPO heated & $2.2 \quad(8)$ & $3.1^{\prime \prime}(6)$ & - & - & $6.4 \S(8)$ \\
\hline \multicolumn{6}{|l|}{ MPO (human) $+\mathrm{H}_{2} \mathrm{O}_{2}$} \\
\hline+ cofactor & $47.2 \S \quad(4)$ & $21.2 \S(3)$ & - & - & $12.7 \S(5)$ \\
\hline $\mathrm{H}_{2} \mathrm{O}_{2}$ omitted & $3.8^{\|} \quad(4)$ & $3.2(4)$ & - & - & $1.9(4)$ \\
\hline
\end{tabular}

* The complete reaction mixture contained $0.03 \mathrm{M}$ sodium phosphate buffer $\mathrm{pH} 6.5,50 \mu \mathrm{g}$ human albumin, $1.5 \mathrm{mM} \mathrm{KH}_{2} \mathrm{PO}_{4}, 1.5 \mathrm{mM} \mathrm{MgSO}{ }_{4}, 5 \times 10^{6}$ platelets labeled with $\left[{ }^{3} \mathrm{H}\right]$ serotonin and $\left[{ }^{14} \mathrm{C}\right]$ adenine, and the supplements listed below as follows: MPO (canine or human) $4 \mathrm{mU}$; $\mathrm{H}_{2} \mathrm{O}_{2} 20 \mu \mathrm{M} ; \mathrm{NaCl} 0.1 \mathrm{M} ; \mathrm{NaI} 0.1 \mathrm{mM} ; \mathrm{NaBr} 0.1 \mathrm{mM} ; \mathrm{NaCNS} 0.1 \mathrm{mM} . \mathrm{Na}_{2} \mathrm{SO}_{4} 0.067 \mathrm{M}$ was added to all reaction mixtures which did not contain $\mathrm{NaCl}$ to maintain isomolarity. MPO was heated at $100^{\circ} \mathrm{C}$ for $15 \mathrm{~min}$ where indicated. Total volume was $0.5 \mathrm{ml}$. Incubation time was $10 \mathrm{~min}$.

$\ddagger$ Mean of experiments. No. of experiments in parentheses. Release in control samples (mean $9.2 \pm 0.6 \%$ ) was subtracted from that in experimental samples.

$\S P<0.001$ vs. control.

" $P<0.05$ vs. control.

serotonin or adenine above control levels in the absence of the peroxidase system components. EDTA, DNP, and DOG did not inhibit protein iodination by the MPO- $\mathrm{H}_{2} \mathrm{O}_{2}$-halide system (32), which suggests that

TABLE II

Effect of Inhibitors on Release of $\left.{ }^{3} \mathrm{H}\right]$ Serotonin from Platelets by the MPO- $\mathrm{H}_{2} \mathrm{O}_{2}$-Chloride System *

\begin{tabular}{lc}
\hline \multicolumn{1}{c}{ Inhibitors } & {$\left[{ }^{3} \mathrm{H}\right]$ Serotonin release } \\
\hline & $\%$ \\
None & $50.0 \pm 2.5 \ddagger(24)$ \\
Azide $(0.1 \mathrm{mM})$ & $2.5 \pm 1.0 \S(8)$ \\
Cyanide $(0.1 \mathrm{mM})$ & $3.8 \pm 1.4 \S(8)$ \\
Catalase $(210 \mathrm{U})$ & $1.5 \pm 0.5 \S(6)$ \\
Heated catalase $(210 \mathrm{U})$ & $55.1 \pm 8.8(6)$ \\
EDTA $(10 \mathrm{mM})$ & $9.4 \pm 0.9 \S(5)$ \\
EDTA $(1 \mathrm{mM})$ & $44.6 \pm 3.2(4)$ \\
Mg-EGTA $(10 \mathrm{mM})$ & $60.2 \pm 5.9(5)$ \\
DNP $(10 \mu \mathrm{M})$ & $33.5 \pm 3.1 \S(11)$ \\
DOG $(1 \mathrm{mM})$ & $29.2 \pm 3.6 \S(11)$ \\
DNP $(10 \mu \mathrm{M})+$ DOG $(1 \mathrm{mM})$ & $13.4 \pm 2.4 \S(10)$
\end{tabular}

* Conditions were the same as described for the $\mathrm{MPO}-\mathrm{H}_{2} \mathrm{O}_{2}$ chloride system in Table I except for the addition of inhibitors as noted. Azide and cyanide were added as the sodium salts. Canine MPO was used.

$\ddagger$ Mean \pm SE. No. of experiments is in parentheses. Release in control samples (mean $9.2 \pm 0.6 \%$ ) was subtracted from that in experimental samples.

$\S P<0.001$ vs. complete MPO system. their inhibitory activity in these experiments was not a consequence of blocking the peroxidase system, but rather was mediated by an effect on the platelets.

\section{DISCUSSION}

A number of investigators have demonstrated effects of reagent $\mathrm{H}_{2} \mathrm{O}_{2}$ on certain aspects of platelet function, although these studies have employed rather high concentrations of $\mathrm{H}_{2} \mathrm{O}_{2}$, generally well in excess of $0.1 \mathrm{mM}$. Although platelet aggregation by $\mathrm{H}_{2} \mathrm{O}_{2}$ has been reported (24), Canoso et al. (25) demonstrated no aggregation by this agent alone, but enhancement of the response to other agents (e.g., ADP) added simultaneously with the $\mathrm{H}_{2} \mathrm{O}_{2}$. Under some conditions, preincubation of platelets with $\mathrm{H}_{2} \mathrm{O}_{2}$ may impair subsequent aggregation responses to ADP or other agents $(25,26)$. Ultrastructural studies indicated aggregation of platelets exposed to $\mathrm{H}_{2} \mathrm{O}_{2}$ in concentrations $>1 \mathrm{mM}$ (26). $\mathrm{H}_{2} \mathrm{O}_{2}$ has not been reported to cause serotonin release from platelets (25) except in concentrations exceeding $1 \mathrm{mM}(26)$. Holmsen and colleagues $(27,28)$ noted that incubation of platelets in $\mathrm{H}_{2} \mathrm{O}_{2}(\geq 0.1 \mathrm{mM})$ resulted in decreases in platelet ATP, but the adenylate energy charge decreased only if ATP levels were more than two-thirds depleted. Under these conditions, $\mathrm{H}_{2} \mathrm{O}_{2}$ caused inhibition of shape change, primary aggregation, and secretion of constituents of dense granules and $\alpha$-granules only if the decrease in adenylate energy charge exceeded 5\%. Handin et al. (33) 
described the initiation of platelet aggregation and serotonin release by xanthine oxidase, a superoxidegenerating enzyme. Inhibition of these effects by superoxide dismutase, but not catalase or mannitol, suggested mediation by superoxide rather than $\mathrm{H}_{2} \mathrm{O}_{2}$ or hydroxyl radical. Longer incubation of platelets with xanthine oxidase caused release of radioactive sodium chromate, a cytoplasmic label, and this was blocked by catalase, but not superoxide dismutase. It was thus suggested that superoxide caused specific release of granule components, whereas $\mathrm{H}_{2} \mathrm{O}_{2}$ (formed by superoxide dismutation) caused lytic damage to the platelet.

Our data document the release of platelet constituents by the MPO- $\mathrm{H}_{2} \mathrm{O}_{2}$-halide system. The release of serotonin, a dense-granule constituent, was employed as an indicator of the platelet release reaction, whereas the release of adenine was considered to be a lytic or cytotoxic event $(34,35)$. If both serotonin and adenine are solubilized, but the former predominates, it may be inferred that both the release reaction and lysis are occurring.

Under our experimental conditions, brief exposure of platelets to $\mathrm{H}_{2} \mathrm{O}_{2}$ alone $(20 \mu \mathrm{M})$ resulted in a small, although significant, release of adenine as well as serotonin, suggesting some platelet lysis. $\mathrm{H}_{2} \mathrm{O}_{2}$ alone initiated a large amount of release of these markers only at higher concentrations $(>0.1 \mathrm{mM})$, or on prolonged exposure ( $1-2 \mathrm{~h}$ ) to low concentrations. Serotonin release by $\mathrm{H}_{2} \mathrm{O}_{2}$ was markedly enhanced by the addition of MPO and a halide. The amount of adenine

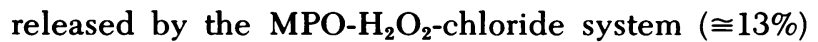
was considerably less than the serotonin release $(50 \%)$, which suggests that the peroxidase system triggers the nonlytic secretion of granule constituents independent of a lytic effect. Each component of the system (MPO, $\mathrm{H}_{2} \mathrm{O}_{2}$, halide) was required, and either chloride, bromide, iodide, or the pseudohalide, thiocyanate, could be employed. Chloride was effective in physiologic concentrations $(0.1 \mathrm{M})$. Relatively low concentrations of $\mathrm{H}_{2} \mathrm{O}_{2}(10 \mu \mathrm{M})$ could be employed, and serotonin release reached maximum levels in 2-5 min. Serotonin release by the MPO system was inhibited by the heme enzyme inhibitors, azide and cyanide, as well as by catalase. Although the inhibition by azide and cyanide appears to be a result of an effect on the peroxidase, it should be noted that azide, but not cyanide, inhibits the platelet aggregation and release responses to collagen, ADP, and epinephrine by a direct effect on the platelet, the mechanism of which remains to be determined $(27,36)$.

Chelation of $\mathrm{Ca}^{2+}$ by Mg-EGTA did not inhibit MPOinduced serotonin release, whereas chelation of both $\mathrm{Ca}^{2+}$ and $\mathrm{Mg}^{2+}$ by EDTA did, suggesting a requirement for $\mathrm{Mg}^{2+}$. DNP, an inhibitor of oxidative phosphorylation, partially blocked serotonin release, as did DOG, a glycolytic inhibitor, and maximal inhibition was achieved by a combination of DNP and DOG. Other aspects of platelet function are also maximally inhibited by simultaneously blocking oxidative and glycolytic pathways (37-40). This requirement for intact platelet metabolism to observe maximal release responses to the MPO system suggests an active process with respect to the platelets, as opposed to a passive lytic or cytotoxic process.

Thus, several lines of evidence indicate that the release of serotonin from platelets by the MPO system is primarily a nonlytic event analogous to the release reaction (34). This hypothesis is supported by the rapidity of release, the marked predominance of serotonin release over adenine release, the divalent cation requirement, and the necessity for intact platelet metabolic activity. A lesser component of lytic release appears to be associated with a nonenzymatic effect of $\mathrm{H}_{2} \mathrm{O}_{2}$ alone.

In view of the ability of the MPO system to release platelet granule constituents and the known secretion of MPO and $\mathrm{H}_{2} \mathrm{O}_{2}$ by activated PMN $(1,2,4-13)$, it is reasonable to suggest an interaction between PMN and platelets mediated by this system. Levine et al. (8) have demonstrated that $\mathrm{H}_{2} \mathrm{O}_{2}$ formed by phagocytosing PMN can inhibit platelet aggregation responses to ADP. Their protocol, in which the PMN and platelets were separated by a dialysis membrane, might preclude the detection of an MPO-mediated effect as the large molecular weight of this enzyme $(41,42)$ would not allow passage through the membrane. It would be expected that an $\mathrm{H}_{2} \mathrm{O}_{2}$-mediated effect would be considerably enhanced by MPO in the presence of a suitable halide cofactor. Platelets contain $\mathrm{H}_{2} \mathrm{O}_{2}$-degrading enzyme systems (e.g., catalase and glutathione peroxidase $[8,27,43]$ ) which may limit perturbation by low levels of $\mathrm{H}_{2} \mathrm{O}_{2}$. The protective effect of these enzymes might be overcome by increased $\mathrm{H}_{2} \mathrm{O}_{2}$ levels, by persisting low steady-state levels, or by successful competition for $\mathrm{H}_{2} \mathrm{O}_{2}$ by MPO.

Our studies, together with those of others $(8,22,33)$, suggest that activated PMN might influence platelets by several mechanisms, including superoxide anion, $\mathrm{H}_{2} \mathrm{O}_{2}$, or the MPO- $\mathrm{H}_{2} \mathrm{O}_{2}$-halide system. Further, the effect on platelets may be primary, i.e., initiation of release reactions, or secondary, i.e., impairment of the response to other stimuli. These observations may have important implications for hemostatic processes in vivo. The simultaneous presence of $\mathrm{PMN}$ and platelets in sites of thrombus formation $(44,45)$ raises the distinct possibility that PMN products, such as $\mathrm{MPO}$ and $\mathrm{H}_{2} \mathrm{O}_{2}$, could promote the release of platelet constituents within the developing thrombus.

\section{ACKNOWLEDGMENTS}

The authors gratefully acknowledge the expert technical assistance of Coralie Baker. This work was supported by grants 
CA18354, CA24353, and AI07763 from the U. S. Public Health Service.

\section{REFERENCES}

1. Goldstein, I. M. 1976. Polymorphonuclear leukocyte lysosomes and immune tissue injury. Prog. Allergy. 20: $301-340$.

2. Klebanoff, S. J., and R. A. Clark. 1978. The Neutrophil: Function and Clinical Disorders. Elsevier North-Holland, Inc., New York.

3. Babior, B. M. 1978. Oxygen-dependent microbial killing by phagocytes. N. Engl. J. Med. 298: 659-668, 721-725.

4. Baehner, R. L., D. G. Nathan, and W. B. Castle. 1971. Oxidant injury of caucasian glucose-6-phosphate dehydrogenase-deficient red blood cells by phagocytosing leukocytes during infection. J. Clin. Invest. 50: 2466-2473.

5. Clark, R. A., and S. J. Klebanoff. 1975. Neutrophilmediated tumor cell cytotoxicity. Role of the peroxidase system. J. Exp. Med. 141: 1442-1447.

6. Root, R. K., J. Metcalf, N. Oshino, and B. Chance. 1975 $\mathrm{H}_{2} \mathrm{O}_{2}$ release from human granulocytes during phagocytosis. I. Documentation, quantitation, and some regulating factors. J. Clin. Invest. 55: 945-955.

7. Salin, M. L., and J. M. McCord. 1975. Free radicals and inflammation. Protection of phagocytosing leukocytes by superoxide dismutase. J. Clin. Invest. 56: 1319-1323.

8. Levine, P. H., R. S. Weinger, J. Simon, K. L. Scoon, and N. I. Krinsky. 1976. Leukocyte-platelet interaction. Release of hydrogen peroxide by granulocytes as a modulator of platelet reactions. J. Clin. Invest. 57: 955963.

9. Baehner, R. L., M. J. Karnovsky, and M. L. Karnovsky. 1969. Degranulation of leukocytes in chronic granulomatous disease. J. Clin. Invest. 48: 187-192.

10. Weissmann, G., R. B. Zurier, P. J. Spieler, and I. M. Goldstein. 1971. Mechanisms of lysosomal enzyme release from leukocytes exposed to immune complexes and other particles. J. Exp. Med. 134: 149s-165s.

11. Henson, P. M. 1971. The immunologic release of constituents from neutrophil leukocytes. I. The role of antibody and complement on nonphagocytosable surfaces or phagocytosable particles. J. Immunol. 107: 1535-1546.

12. Henson, P. M., H. B. Johnson, and H. L. Spiegelberg. 1972. The release of granule enzymes from human neutrophils stimulated by aggregated immunoglobulins of different classes and subclasses. J. Immunol. 109: 11821192.

13. Bainton, D. F. 1973. Sequential degranulation of the two types of polymorphonuclear leukocyte granules during phagocytosis of microorganisms. J. Cell Biol. 58: 249264.

14. Klebanoff, S. J. 1975. Antimicrobial mechanisms in neutrophilic polymorphonuclear leukocytes. Semin. Hematol. 12: 117-142.

15. Smith, D. C., and S. J. Klebanoff. 1970. A uterine fluidmediated sperm-inhibitory system. Biol. Reprod. 3: 229-235.

16. Klebanoff, S. J., and R. A. Clark. 1975. Hemolysis and iodination of erythrocyte components by a myeloperoxidase-mediated system. Blood. 45: 699-707.

17. Clark, R. A., and S. J. Klebanoff. 1977. Myeloperoxidase$\mathrm{H}_{2} \mathrm{O}_{2}$-halide system: Cytotoxic effect on human blood leukocytes. Blood. 50: 65-70.

18. Clark, R. A., S. J. Klebanoff, A. B. Einstein, and A. Fefer. 1975. Peroxidase- $\mathrm{H}_{2} \mathrm{O}_{2}$-halide system: Cytotoxic effect on mammalian tumor cells. Blood. 45: 161-170.
19. Klebanoff, S. J., and C. B. Hamon. 1972. Role of myeloperoxidase-mediated antimicrobial systems in intact leukocytes. J. Reticuloendothel. Soc. 12: 170-196.

20. Odeberg, H., T. Olofsson, and I. Olsson. 1974. Myeloperoxidase-mediated extracellular iodination during phagocytosis in granulocytes. Scand. J. Haematol. 12: 155-160.

21. Harrison, M. J. G., P. R. Emmons, and J. R. A. Mitchell. 1966. The effect of white cells on platelet aggregation. Thromb. Diath. Haemorrh. 16: 105-121.

22. Henson, P. M. 1970. Mechanisms of release of constituents from rabbit platelets by antigen-antibody complexes and complement. II. Interaction of platelets with neutrophils. J. Immunol. 105: 490-501.

23. Handin, R. I., and T. P. Stossel. 1974. Phagocytosis of antibody-coated platelets by human granulocytes. $N$. Engl. J. Med. 290: 989-993.

24. Higashi, O., Y. Kikuchi, and K. Konno. 1972. A case of thrombasthenia with a study of platelet aggregation by hydrogen peroxide $\left(\mathrm{H}_{2} \mathrm{O}_{2}\right)$. Tohoku J. Exp. Med. 106: 399-409.

25. Canoso, R. T., R. Rodvien, K. Scoon, and P. H. Levine. 1974. Hydrogen peroxide and platelet function. Blood. 43: 645-656.

26. Rodvien, R., J. N. Lindon, and P. H. Levine. 1976. Physiology and ultrastructure of the blood platelet following exposure to hydrogen peroxide. $\mathrm{Br}$. J. Haematol. 33: 19-26.

27. Holmsen, H., and L. Robkin. 1977. Hydrogen peroxide lowers ATP levels in platelets without altering adenylate energy charge and platelet function. J. Biol. Chem. 252: 1752-1757.

28. Stuart, M. J., and H. Holmsen. 1977. Hydrogen peroxide, an inhibitor of platelet function: Effect on adenine nucleotide metabolism, and the release reaction. Am. J. Hematol. 2: 53-63.

29. Agner, K. 1958. Crystalline myeloperoxidase. Acta Chem. Scand. 12: 89-94.

30. Worthington Enzyme Manual. 1972. Worthington Biochemical Corp., Freehold, N. J. 43.

31. Olsson, I., T. Olofsson, and H. Odeberg. 1972. Myeloperoxidase-mediated iodination in granulocytes. Scand.J. Haematol. 9: 483-491.

32. Klebanoff, S. J. 1967. Iodination of bacteria. A bactericidal mechanism. J. Exp. Med. 126: 1063-1078.

33. Handin, R. I., R. Karabin, and G. J. Boxer. 1977. Enhancement of platelet function by superoxide anion. J. Clin. Invest. 59: 959-965.

34. Day, H. J., and H. Holmsen. 1971. Concepts of the blood platelet release reaction. Ser. Haematol. 4: 3-27.

35. Reimers, H. J., J. F. Mustard, and M. A. Packham. 1975. Transfer of adenine nucleotides between the releasable and nonreleasable compartments of rabbit blood platelets. J. Cell Biol. 67: 61-71.

36. Stibbe, J., and H. Holmsen. 1977. Effects of sodium azide on platelet function. Thromb. Haemostasis. 38: 10421053.

37. Ball, G., M. Fulwood, D. M. Ireland, and P. Yates. 1969. Effect of some inhibitors of platelet aggregation on platelet nucleotides. Biochem. J. 114: 669-671.

38. Murer, E. H. 1969. Clot retraction and energy metabolism of platelets. Effect and mechanism of inhibitors. Biochim. Biophys. Acta. 172: 266-276.

39. Holmsen, H., C. A. Setkowsky, and H. J. Day. 1974. Effects of antimycin and 2-deoxyglucose on adenine nucleotides in human platelets. Role of metabolic adenosine triphosphate in primary aggregation, secondary aggrega- 
tion and shape change of platelets. Biochem. J. 144: 385-396.

40. Kattlove, H. E. 1974. Platelet ATP in ADP-induced aggregation. Am. J. Physiol. 226: 325-329.

41. Ehrenberg, A., and K. Agner. 1958. The molecular weight of myeloperoxidase. Acta Chem. Scand. 12: 95-100.

42. Felberg, N. T., and J. Schultz. 1972. Evidence that myeloperoxidase is composed of isoenzymes. Arch. Biochem. 148: 407-413.
43. Karpatkin, S., and H. J. Weiss. 1972. Deficiency of glutathione peroxidase associated with high levels of reduced glutathione in Glanzmann's thrombasthenia. N. Engl. J. Med. 287: 1062-1066.

44. Henry, R. L. 1965. Leukocytes and thrombosis. Thromb. Diath. Haemorrh. 13: 35-46.

45. Jørgensen, L., H. C. Rowsell, T. Hovig, and J. F. Mustard. 1967. Resolution and organization of platelet-rich mural thrombi in carotid arteries of swine. Am. J. Pathol. 51: 681-719. 